\section{PENGARUH DIVERSIFIKASI PRODUK ELEKTRONIK DAN REPUTASI PERUSAHAAN TERHADAP MINAT BELI ULANG PELANGGAN PADA UD.MEKAR SARI DI PRAYA LOMBOK TENGAH}

\author{
Baiq Febrina Dwi Muliati1) \\ Hermanto ${ }^{2)}$ \\ Edy Herman Mulyono2) \\ Email: baiqfebrina01@gmail.com
}

\begin{abstract}
This thesis is aimed at analyzing the effect of diversification of electronic products and the reputation of company on the repurchase interest in UD. Mekar Sari in Praya Central Lombok. This research is to analyse the effect of variable of company reputation on the repurchase interest in UD. Mekar Sari. This research is an associative study with all consumers buyimg the electronic products as the research population. The sample were 100 respondents. The data were analysed using SPSS.The research showed that Diversification of Electronic Products conducted by UD. Mekar Sari providing the various types, brands, and size of products has positive and significant effect on the repurchase interest of consuumers. The Company reputation was measured with the company's competence, excellee, trust of cconsumers, the company's experience had positive and significant effect on the repurchase interest in UD. Mekkar Sari.
\end{abstract}

Keywords: Product Diversification, Company Reputation, Repurchase Interest

\section{PENDAHULUAN}

Keadaan perekonomian yang semakin sulit menyebabkan persaingan di berbagai bidang kehidupan semakin ketat, termasuk didalamnya persaingan dalam dunia bisnis. Banyak pengusaha saling berlomba untuk mendapatkan pangsa pasar demi mempertahankan kelangsungan hidup perusahaannya (Ramli, 2008). Hal ini memacu pengusaha untuk memperbaiki usahanya agar tetap dapat mencapai tujuan perusahaan. Baik itu untuk memperoleh laba optimal, mengembangkan perusahaan ataupun memperkuat posisi dalam menghadapi pesaing.

Agar tumbuh dan berkembang dengan baik, maka perusahaan harus dapat mengantisipasi perkembangan ekonomi yang semakin tidak menentu dengan melakukan berbagai inovasi, terobosan serta strategi pemasaran yang tepat dan bersaing. Dengan melakukan diversifikasi produk. Diversifikasi produk ini adalah upaya yang dilakukan oleh perusahaan untuk memasarkan beberapa produk yang sejenis dengan produk yang sudah dipasarkan sebelumnya (Lauren, 2012). Diversifikasi produk dilakukan oleh pemasar agar dapat memberikan kepuasan bagi konsumen dengan berbagai varian produk yang ditawarkan.

${ }^{(1)}$ Magister Manajemen Pascasarjana Universitas Mataram 


\section{$J M M$

Penelitian ini bermula dengan adanya inkonsistensi penelitian terdhulu terkait dengan pengaruh diversifikasi produk terhadap reputasi perusahaan dan minat beli ulang konsumen diantaranya, Purba (2005) strategi diversifikasi tipe produk yang dilakukan oleh seuatu perusahaan terbukti mampu meningkatkan reputasi perusahaan. Sementara menurut penelitian Laviunita (2013), strategi Diversifikasi produk melalui penganekaragaman jenis produk berkontribusi positif yang signifikan terhadap meningkatnya minat ulang konsumen. Sementara menurut Oetomo (2009) diversifikasi produk dalam bentuk keragaman menu berpengaruh positif terhadap minat beli ulang konsumen. Anderson (dalam Kuntjara,1994) variabel reputasi perusahaan dapat menstimulasi terjadinya pembelian ulang. Sari (2013) perusahaan yang ingin konsumen membeli ulang produknya juga harus memperhatikan masalah reputasi perusahaan. Kuntjara (2007) menemukan bahwa reputasi perusahaan termasuk salah satu faktor yang dapat mempengaruhi minat beli ulang konsumen. Namun, menurut Laviunita (2013) variabel reputasi perusahaan yang diukur dengan kompetensi perusahaan, keunggulan perusahaan, kepercayaan pelanggan terhadap perusahaan dan pengalaman perusahaan ternyata tidak berpengaruh positif signifikan terhadap minat beli ulang yang dilakukkan oleh konsumen.

UD.Mekar Sari didirikan pada tahun 1991 oleh pemiliknya yang bernama Hj. Baiq Sumiati dan saat ini memiliki 8 orang karyawan.Awalnya toko ini hanya menjual barang pecah belah saja. Namun dengan seiringnya waktu semakin banyak konsumen dan persaingan usaha yang semakin meningkat sejak 10 tahun yang lalu tepatnya pada tahun 2006 barulah UD.Mekar Sari memulai menjual barang-barang elektronik dengan berbagai merek yang lebih beragam dibandingkan dengan ud sejenis yang menjadi pesaingannya. Selain itu juga UD. Mekar Sari menawarkan pembayaran secara kredit dan cash.

Pada tahun 2012 saat pertama kali UD. Mekar Sari mulai menambahkan produk elektronik untuk diatawarkan pada konsumen dengan penjuallan mencapai 140 unit dan di tahun 2013 penjuallan meningkat menjadi 149 unit. Namun,pada tahun 2014 terjadi penurunan penjualan unit yang signifikan menjadi 129 unit (Sumber; UD. Laporan Data Penjualan Mekar Sari Tahun tahun 2012- 2016). Penurunan yang terjadi disebabkan oleh hadirnya beberapa toko elektronik baru seperti toko Unggul Jaya dan Global di daerah Praya. Sejak saat itu, persaingan dirasakan semakin ketat sehingga perusahaan mulai melakukan strategi untuk mempertahankan dan menciptakan peluang pasar baru dengan melakukan diversifikasi produk elektronik. Hal ini dilakukkan perusahaan agar tidak mengalami kemunduran ataupun tergeser dari persaingan yang semakin ketat. Sehingga penjualan unit mulai stabil lagi setiap tahunnya.

Penelitian terkait Variabel-variabel seperti di versiifikasi produk, reputasi perusahaan dan minat beli ulang masih sangat jarang diteliti terutama terkait pengaruh diversifikasi produk pada usaha local dalam skala Usaha Dagang (UD) sebagai objek penelitian. Penelitian ini salah satunya untuk mengisi gap tersebut.

\section{METODE PENELITIAN}

\section{Jenis Penelitian}

Penelitian ini adalah asosiatif, yaitu suatu jenis penelitian yang bertujuan untuk mengetahui hubungan antara dua variabel atau lebih. Penelitian asosiatif mempunyai tingkatan yang lebih tinggi di bandingkan dengan penelitian deskriptif maupun 


\section{$J M M$

komparatif (Sugiyono:2005). Penelitian kali ini ingin menganalisis hubungan dari variabelvariabel dalam diversifikasi produk elektronik seperti jenis produk, merek produk, ukuran produk dan tipe produk (variabel bebas) dalam mempengaruhi reputasi perusahaan (variabel moderator) dan minat beli ulang konsumen (variabel terikat) pada UD. Mekar Sari

\section{Populasi sampel Sampel Penelitian}

Populasi dalam penelitian ini adalah semua pelanggan yang membeli produk elektronik di UD. Mekar Sari. Karena populasi yang cukup besar, maka metode pengumpulan data yang digunakan adalah Sampel Survey. Sementara sampel dalam penelitian ini adalah beberapa konsumen yang datang dan sudah melakukan pembelian pada UD. Mekar Sari. Responden yang dijadikan sampel sebanyak 100 orang. Teknik pengambilan sampel dilakukan dengan menggunakan Accidental Sampling.

\section{Deskripsi Karakteristik Responden}

Dalam penelitian ini akan dilakukan analisis data yang diperoleh berdasarkan jawaban dari 100 orang responden atas pernyataan yang diajukan dalam kuesioner. Hasil penelitian menggambarkan tanggapan responden tentang pengaruh variabel diversifikasi produk elektronik dengan indikator jenis produk, merek produk, ukuran produk, dan tipe produk dan reputasi perusahaan terhadap minat beli ulang konsumen pada UD. Mekar Sari Data yang diperoleh mengenai responden antara lain mengenai jenis kelamin, usia, pendidikan, pekerjaan dan pendapatan.

\section{Tabel 1;}

Karakteristik Responden Penelitian

\begin{tabular}{llcc}
\hline $\begin{array}{c}\text { Karakteristik } \\
\text { Responden }\end{array}$ & $\begin{array}{c}\text { Kategori } \\
\text { Pengelompokan }\end{array}$ & $\begin{array}{c}\text { Jumlah } \\
\text { (Orang) }\end{array}$ & $\begin{array}{c}\text { Persentase } \\
\mathbf{( \% )}\end{array}$ \\
\hline Jenis Kelamin & Laki-laki & 49 & 49 \\
& Wanita & 51 & 51 \\
& Total & 100 & 100 \\
\hline Usia (Tahun) & <20 Tahun & 10 & 10 \\
& 21-30 Tahun & 43 & 43 \\
& 31-40 Tahun & 31 & 31 \\
& 41-50 Tahun & 15 & 15 \\
& >51 Tahun & 1 & 1 \\
& Total & $\mathbf{1 0 0}$ & $\mathbf{1 0 0}$ \\
\hline Pingkat & SD & 7 & 7 \\
& SMP & 17 & 17 \\
& SMA & 45 & 45 \\
& S1/SEDERAJAT & 29 & 29 \\
& S2,S3/SEDERAJAT & 2 & 2 \\
& Total & $\mathbf{1 0 0}$ & $\mathbf{1 0 0}$ \\
\hline Pekerjaan & Wiraswasta & 10 & 10 \\
& Karyawan swasta & 25 & 25 \\
& PNS & 16 & 16 \\
& Ibu Rumah Tangga & 33 & 33 \\
& Lain-lain & 16 & 16 \\
& Total & $\mathbf{1 0 0}$ & $\mathbf{1 0 0}$ \\
\hline
\end{tabular}

(Sumber; data primer diolah) 


\section{JMM

Karakteristik responden berdasarkan jenis kelamin dapat kita lihat bahwa jumlah responden laki-laki dan perempuan hampir sebanding yaitu masing-masing berjumlah 49 orang laki-laki dan 51 orang perempuan. Hal ini menunjukkan bahwa konsumen produk elektronik tidak dominan adalah laki-laki maupun perempuan saja. Sebagian besar konsumen yang membeli produk elektronik adalah konsumen yang sudah berkeluarga sehingga pembelian produk dipertimbangkan bersama.

Karakteristik responden brdasarkan usia. Berdasarkan Tabel 1 dapat dilihat bahwa dari hasil penelitian yang telah dilakukan sebagian besar responden dalam penelitian ini berusia antara 21-30 tahun yaitu sejumlah 43 orang (43 persen). Hal ini menunjukkan bahwa responden terbanyak yang melakukan pembelian produk elektronik pada UD. Mekar Sari adalah mereka yang usianya berkisar antara 21-30 tahun, karena pembelian produk elektronik dominan dilakukan oleh konsumen dewasa yang sudah berkeluarga. Sebaliknya, responden yang paling sedikit adalah responden dengan usia $\geq 51$ tahun yaitu hanya seorang saja. Hal ini karena mereka yang berada pada usia sekian biasanya mempercayakan kerabatnya yang lebih muda untuk menentukan pilihan dan melakukan pembelian produk elektronik.

Dari segi tingkat pendidikan bahwa sebagian besar responden dalam penelitian ini pendidikan terakhirnya adalah SMA yaitu sejumlah 45 orang (45 persen). Hal ini men dikarenakan responden yang memiliki pendidikan tinggi di Praya lebih memilih membeli produk elektronik di Kota Mataram yang menyediakan lebih banyak produk produk elektronik dan yang terbaru.

Untuk pengelompokan responden berdasarkan pekerjaan diperoleh hasil bahwa sebagian besar responden dalam penelitian ini memiliki pekerjaan sebagai ibu rumah tangga sejumlah 33 orang (33 persen). Artinya, pembelian produk elektronik pada UD. Mekar Sari lebih banyak dilakukan oleh ibu rumah tangga. Hal ini disebabkan karena produk elektronik dominan digunakan oleh mereka yang sudah berkeluarga dan seringkali ditentukan oleh keinginan istri. Responden yang memiliki pekerjaan sebagai wiraswasta adalah responden dengan jumlah paling sedikit yaitu hanya 10 orang saja. Hal ini karena mayoritas masyarakat di Praya bekerja sebagai karyawan swasta dan PNS, hanya sebagian kecil saja yang memiliki usaha sendiri.

Karakteristik responden berdasarkan tingkat pendapatan. Dari hasil penelitian yang telah dilakukan sebagian besar responden dalam penelitian ini memiliki pendapatan sebesar 1-3 juta sejumlah 43 orang (43 persen). Artinya, pendapatan masyarakat di Praya yang berbelanja pada UD. Mekar Sari lebih banyak dilakukan oleh masyarakat yang memiliki pendapatan 1-3 juta. Hal ini disebabkan karena rata-rata masyarakat di Praya bekerja sebagai karyawan swasta dan PNS. Responden yang memiliki pendapatan di atas 3 juta sebesar 30 orang atau 30 persen dan responden dengan jumlah pendapatan paling sedikit yaitu hanya 27 orang memiliki pendapatan di bawah 1 juta. 


\section{$J M M$

Prosedur Analisa Data

Uji Validitas dan Reliabilitas

Tabel 2 Hasil Uji Validitas dan uji reliabilitas

\begin{tabular}{|c|c|c|c|c|c|c|}
\hline \multicolumn{5}{|c|}{ Uji Validitas } & \multicolumn{2}{|c|}{ Uji Reliabilitas } \\
\hline Variabel & Item & r hitung & $r$ tabel & Keterangan & $\begin{array}{l}\text { Cronbach } \\
\text { 's Alpha }\end{array}$ & Keterangan \\
\hline Difersifikasi & $\mathrm{X} 1.1$ & 0,752 & & Valid & & \\
\hline Produk & $\mathrm{X} 1.2$ & 0,624 & 0,30 & Valid & 0.739 & Reliabel \\
\hline$(\mathrm{X} 1)$ & $\mathrm{X} 1.3$ & 0,682 & & Valid & & \\
\hline & $\mathrm{X} 1.4$ & 0,554 & & Valid & & \\
\hline Reputasi & $\mathrm{X} 2.1$ & 0,717 & & Valid & & \\
\hline Perusahaan & $\mathrm{X} 2.2$ & 0,750 & 0,30 & Valid & 0.823 & Reliabel \\
\hline$(\mathrm{X} 2)$ & $X 2.3$ & 0,715 & & Valid & & \\
\hline & $\mathrm{X} 2.4$ & 0,704 & & Valid & & \\
\hline Niat Beli Ulang & Y1.1 & 0,853 & & Valid & 0.890 & Reliabel \\
\hline$(\mathrm{Y})$ & $\mathrm{Y} 1.2$ & 0,883 & 0,30 & Valid & & \\
\hline
\end{tabular}

Sumber: data sekunder diolah

Berdasarkan tabel 2 tersebut, hasil uji validitas yang dilakukan bahwa semua item pertanyaan dalam tabel tersebut dapat dikatakan valid atau data layak diolah lebih lanjut karena semua item $r$ hitung lebih besar dari $r$ tabel. Demikian jugan dengan hasil uji reliabilitas. Berdasarkan pada Tabel 2 di atas, dapat diketahui bahwa nilai Cronbach's Alpha pada masing-masing variabel menunjukkan nilai yang disyaratkan lebih besar dari 0,60 dengan demikian keseluruhan pernyataan didalam kuesioner Reliabel.

\section{Analisis Statistik}

\section{Analisis Regresi Linier Berganda}

Teknik analisis data yang digunakan adalah Analisis regresi linier berganda. Regresi linier berganda digunakan karena terdapat dua variabel yaitu variabel bebas $X$ dan variabel terikat $Y$, lalu akan dihitung atau dicari nilai $Y$ yang lain berdasarkan nilai $X$ yang sudah ada. Model matematis dari analisis regresi berganda menurut Sugiyono (2006) adalah:

$$
\mathrm{Y}=\alpha+\beta_{1} \mathrm{X}_{1}+\beta_{2} \mathrm{X}_{2}+e
$$

Keterangan :

$\mathrm{Y}=$ Minat Beli Ulang

$\mathrm{a}=$ Konstan

$\mathrm{X}_{1}=$ Diversifikasi Produk

$\mathrm{X}_{2}=$ Reputasi Perusahaan

$\mathrm{b}_{1}=$ Koefisien regresi untuk $\mathrm{X}_{1}$

$\mathrm{b}_{2}=$ Koefisien regresi untuk $\mathrm{X}_{2}$

e $=$ Standar eror

\section{HASIL DAN PEMBAHASAN}

Deskripsi Variabel Penelitian Variabel Diversifikasi Produk 


\section{$J M M$

Diversifikasi Produk Elektronik, merupakan persepsi responden terhadap produk elektronik yang ditawarkan oleh UD. Mekar Sari yang meliputi penambahan jenis produk, merek produk, ukuran produk dan tipe produk untuk memberikan keuntungan lebih besar bagi perusahaan.

Tabel 3

Nilai Skor Rata-rata dari Kategori Diversifikas Produk

\begin{tabular}{lcc} 
Indikator & Rata-rata & Kategori \\
\hline Jenis Produk $(\mathrm{X} 1.1)$ & 4,12 & Mendukung \\
Merek Produk $(\mathrm{X} 1.2)$ & 3,62 & Mendukung \\
Ukuran Produk $(\mathrm{X} 1.3)$ & 3,87 & Mendukung \\
Tipe Produk $(\mathrm{X} 1.4)$ & 4,30 & Mendukung \\
\hline Total & $\mathbf{1 5 , 9 2}$ & \\
\hline Rata-Rata Total & $\mathbf{3 , 9 8}$ & Mendukung \\
\hline
\end{tabular}

Sumber : Data diolah

Dari tabel 3 dapat diketahui bahwa rata-rata diversivikasi produk sebesar 3,98,sehingga masuk kategori Mendukung. Hal ini berarti semakin sering divesivikasi produk dilakukan UD, Mekar Sari, maka minat beli ulang konsumen akan ikut meningkat.

\section{Variabel Reputasi Perusahaan (X2)}

Reputasi Perusahaan, dalam halini adalah persepsi responden hasil dari keterkaitan perusahaan dengan riwayat perusahaan melalui berbagai aktifitas dimasa lalu yang akan menjadi sebuah acuan bagi para partner bisnis mengenai kompetensi perusahaan, keunggulan, kepercayaan pelanggan serta pengalaman perusahaan.

Tabel 4

Tanggapan Responden Terkait Variabel Reputasi Perusahaan (X2)

\begin{tabular}{lcl} 
Indikator & Rata-rata & Kategori \\
\hline Kompetensi Perusahaan (X2.1) & 3,97 & Mendukung \\
Keunggulan Perusahaan (X2.2) & 4,36 & Mendukung \\
Kepercayaan Pelanggan Terhadap & 3,92 & Mendukung \\
Perusahaan (X2.3) & 3,96 & Mendukung \\
Pengalaman perusahaan (X2.4) & $\mathbf{1 6 , 2 2}$ & \\
\hline Total & $\mathbf{4 , 0 6}$ & Mendukung \\
\hline Rata-Rata Total & & \\
\hline
\end{tabular}

Sumber : Data diolah

Dari tabel 4 dapat diketahui bahwa rata-rata reputasi perusahaan sebesar 4,05, sehingga masuk kategori Mendukung. Hal ini berarti semakin positif/tinggi reputasi UD, Mekar SARI dimata pelangganya, maka minat beli ulang konsumen akan ikut meningkat.

\section{Variabel Minat Beli Ulang (Y)}

Minat Beli Ulang, dalam halini adalah persepsi responden yang cenderung untuk membeli kembali ataupun mengambil tindakan yang relevan seperti merekomendasikan kepada orang lain apa yang sudah diperoleh dari UD. Mekar Sari. 


\section{$J M M$

Tabel 5

Tanggapan Responden Tentang Rencana Membeli Kembali

\begin{tabular}{lcc}
\hline Indikator & Rata-rata & Kategori \\
\hline $\begin{array}{l}\text { Rencana untuk membeli kembali } \\
\text { produk yang dibutuhkan (Y1) }\end{array}$ & 4,29 & Mendukung \\
$\begin{array}{l}\text { Kecenderungan untuk } \\
\text { merekomendasikan kepada orang } \\
\text { lain (Y2) }\end{array}$ & 3,88 & Mendukung \\
\hline Total & 8,17 & \\
\hline Rata-Rata Total & $\mathbf{4 , 0 9}$ & Mendukung \\
\hline Sumber : Data diolah & &
\end{tabular}

Dari tabel 5 dapat diketahui bahwa rata-rata minat beli ulang sebesar 4,09, sehingga masuk kategori Mendukung. Hal ini menunjukan bahwa konsumen UD, Mekar SARI akan melakukan pembelian kembali produk tersebut akan mengusulkan kepada orang lain untuk membeli produk elektronik pada UD.Mekar Sari.

\section{Hasil Analisis Regresi Berganda}

Pengujian hipotesis pada penelitian ini dilakukan dengan menggunakan program SPSS 16.0 untuk menganalisis hubungan pengaruh diversifikasi produk elektronik (X1) dan reputasi perusahaan (X2) terhadap minat beli ulang (Y) pada UD. Mekar Sari. Model regresi berganda dalam penelitian ini ditunjukkan sebagai berikut:

\section{Tabel 6 Hasil Regresi Berganda}

Coefisien

\begin{tabular}{|c|c|c|c|c|c|c|}
\hline \multirow{2}{*}{\multicolumn{2}{|c|}{ Model }} & \multicolumn{2}{|c|}{$\begin{array}{c}\text { Unstandardized } \\
\text { Coefficients }\end{array}$} & \multirow{2}{*}{$\begin{array}{c}\begin{array}{c}\text { Standardized } \\
\text { Coefficients }\end{array} \\
\text { Beta }\end{array}$} & \multirow[b]{2}{*}{$\mathrm{t}$} & \multirow[b]{2}{*}{ Sig. } \\
\hline & & B & Std. Error & & & \\
\hline 1 & (Constant) & .284 & .409 & & .693 & .490 \\
\hline & $\mathrm{X} 1$ & .272 & .097 & .229 & 2.795 & .006 \\
\hline & $X 2$ & .671 & .098 & .561 & 6.839 & .000 \\
\hline
\end{tabular}

a. Dependent Variable: $Y$

Berdasarkan Tabel 6 di atas maka dapat dibentuk persamaan regresi dari variabel dependen dan independen sebagai berikut:

$\mathrm{Y}=0.284+0.272 \mathrm{X}_{1}+0.671 \mathrm{X}_{2}+e$

Dimana: $Y=$ Minat Beli Ulang, $X_{1}=$ Diversifikasi Produk, dan $X_{2}=$ Reputasi Perusahaan. Berdasarkan model regresi berganda tersebut selanjutnya akan dianalisis mengenai pengaruh variabel independen terhadap variabel dependen. Interpretasi model persamaan regresi tersebut adalah:

Fungsi linier tersebut di atas dapat dijabarkan sebagai berikut.

Nilai konstanta sebesar 0.284 berarti bahwa apabila masing-masing variabel independen memiliki nilai 0, maka Minat Beli Ulang bernilai positif sebesar 0.284. Hal ini bermakna bahwa Minat Beli Ulang tetap bernilai positif ketika tidak adanya variabel Diversifikasi Produk dan Reputasi Perusahaan.

Koefisien regresi dari Diversifikasi Produk $\left(b_{1}\right)$ yang bernilai sebesar 0.272 . berarti bahwa apabila variabel Diversifikasi Produk $\left(\mathrm{X}_{1}\right)$ ditambahkan ke dalam model regresi linier, maka Minat Beli Ulang konsumen akan mengalami kenaikan sebesar 0.272. Koefisien 


\section{$J M M$

regresi Diversifikasi Produk $\left(b_{1}\right)$ yang bernilai positif ini bermakna bahwa semakin tinggi atau semakin sering Diversifikasi Produk dilakukan maka Minat Beli Ulang konsumen tersebut akan semakin tinggi. Begitu pula sebaliknya semakin rendah Diversifikasi Produk maka Minat Beli Ulang tersebut akan semakin rendah.

Koefisien regresi dari Reputasi Perusahaan $\left(b_{2}\right)$ yang bernilai 0.671 menjelaskan bahwa apabila variabel Reputasi Perusahaan $\left(\mathrm{X}_{2}\right)$ dimasukkan ke dalam, maka Minat Beli Ulang mengalami peningkatan sebesar 0,381 . Koefisien regresi Keluarga $\left(b_{2}\right)$ yang bernilai positif ini bermakna bahwa semakin tinggi semakin baik Reputasi Perusahaan maka Minat Beli Ulang tersebut akan semakin bertambah. Begitu pula sebaliknya, semakin rendah Reputasi Perusahaan maka Minat Beli Ulang akan semakin rendah.

\section{Hasil Uji Kelayakan Model}

Uji kelayakan model jika hasilnya signifikan maka uji ini dapat digunakan untuk memprediksi model. Untuk melihat bagaimana kelayakan model regresi untukmengetahui pengaruh dari variabel difersifikasi produk dan reputasi perusahaan terhadap Terhadap minat beli ulang konsumen Produk Elektronik UD. Mekar Sari digunakan uji F.

Tabel 7. Hasil Uji Kelayakan Model Regresi Liner Berganda

\begin{tabular}{|c|c|c|c|c|c|c|}
\hline \multicolumn{7}{|c|}{ ANOVA $^{b}$} \\
\hline Model & & $\begin{array}{l}\text { Sum of } \\
\text { Squares }\end{array}$ & Df & Mean Square & $\mathrm{F}$ & Sig. \\
\hline \multirow[t]{3}{*}{1} & Regression & 14.105 & 2 & 7.052 & 45.841 & $.000^{\mathrm{a}}$ \\
\hline & Residual & 14.923 & 97 & .154 & & \\
\hline & Total & 29.027 & 99 & & & \\
\hline
\end{tabular}

a. Predictors: (Constant), X2, X1

b. Dependent Variable: $Y$

Sumber : Data diolah

Berdasarkan Tabel 7, di atas dapat diperoleh $\mathrm{f}_{\text {hitung }}$ sebesar 45.841. Uji kelayakan model dapat dilihat perbandingan dari nilai $f_{\text {hitung }}>f_{\text {tabel }}\left(f_{\text {hitung }} 45.841\right)>\left(f_{\text {tabel }}\right.$ dengan tingkat signifikan sebesar $0,05=3,09)$. Karena nilai $\mathrm{F}_{(\text {Hitung) }}>\mathrm{F}_{\text {(Tabel) }}$ dengan tingkat signifikan 0,000 lebih kecil daripada 0,05. Hasil ini menunjukkan bahwa model regresi yang digunakan dapat dikatakan memenuhi asumsi kelayakan sebuah model penelitian dengan data penelitian yang dianalisis.

\section{Hasil Pengujian Hipotesis}

Pembuktian terhadap hipotesis yang telah disusun dilakukan dengan menggunakan perhitungan regresi melalui bantuan program SPSS versi 16.0 for windows. 


\section{JMM JURNAL MAGISTER MANAJEMEN \\ UNIVERSITAS MATARAM \\ Nopember 2017}

Tabel 8. Hasil Uji t Regresi Linear Barganda

Coefficients ${ }^{a}$

\begin{tabular}{crrr}
\hline Model & $\mathrm{t}$ & \multicolumn{1}{c}{ Sig. } & Keterangan \\
\hline Constant &, 693 & .490 & \\
X1 & 2.795 & .006 & Signifikan \\
X2 & 6.839 & .000 & Signifikan \\
\hline
\end{tabular}

a. Dependent Variable: $Y$

Sumber : Data diolah

\section{Pengaruh Variabel Diversifikasi Produk Terhadap Minat Beli Ulang}

Berdasarkan hasil pengujian yang telah dilakukan dari Tabel 8 terlihat bahwa hasil pengujian hipotesis variabel diversifikasi produk menunjukkan nilai $t_{\text {hitung }}$ sebesar $\mathbf{2 . 7 9 5}$ dengan taraf signifikansi 0,006 yang lebih besar dari nilai $\mathrm{t}_{\text {tabel }}\left(\mathrm{t}_{(\mathrm{\alpha} / 2)(\mathrm{n}-2)}=\mathrm{t}_{(0.05 / 2)(100-2)}=\mathrm{t}_{(0.025 \text {, }}\right.$ ${ }_{98)}=t_{\text {tabel }} 1,984$ (sumber: lampiran 6) dengan nilai signifikansi sebesar 0,006 maka Ho di tolak dan Ha diterima. Dengan demikian dapat disimpulkan bahwa hipotesis pertama yaitu terdapat pengaruh yang signifikan diversifikasi produk terhadap minat beli ulang konsumen di UD.Mekar Sari dapat diterima.

Kedua variabel ini saling terkait dan searah artinya diversifikasi produk yang dilakukan mampu mempengaruhi minat beli ulang konsumen di UD.Mekar Sari. Hal ini bermakna semakin sering diversifikasi produk dilakukan maka akan semakin tinggi pula minat beli ulang konsumen pada di UD.Mekar Sari.

\section{Pengaruh Variabel Reputasi Perusahaan Terhadap Minat Beli Ulang}

Berdasarkan hasil pengujian yang telah dilakukan dari Tabel 8 terlihat bahwa hasil pengujian hipotesis variabel Reputasi Perusahaan menunjukkan nilai $t_{\text {hitung }}$ sebesar 6.839 dengan taraf signifikansi 0,000 yang lebih besar dari nilai $\mathrm{t}_{\text {tabel }}\left(\mathrm{t}_{(\mathrm{\alpha} / 2)(\mathrm{n}-2)}=\mathrm{t}_{(0.05 / 2)(100-2)}=\mathrm{t}_{(0.025 \text {, }}\right.$ ${ }_{98)}=t_{\text {tabel }} 1,984$ (sumber: lampiran 6) dengan nilai signifikansi sebesar 0,000 maka Ho di tolak dan Ha diterima. Dengan demikian dapat disimpulkan bahwa hipotesis kedua yang menyatakan terdapat pengaruh positif signifikan Reputasi Perusahaan terhadap Minat Beli Ulang konsumen di UD.Mekar Sari dapat diterima

Kedua variabel ini saling terkait dan searah artinya Reputasi Perusahaan mampu mempengaruhi Minat Beli Ulang konsumen di UD.Mekar Sari. Hal ini bermakna jika reputasi perusahaan semakin baik maka minat beli ulang konsumen akan ikut meningkat.

\section{Uji Koefisien Determinasi $\left(\mathbf{R}^{2}\right)$}

Koefisien determinasi $\left(\mathrm{R}^{2}\right)$ pada intinya mengukur seberapa jauh kemampuan model dalam menerangkan variasi variabel terikat (Kuncoro, 2007 :84). Uji determinasi (agregat, $\left.R^{2}\right)$ adalah uji kemampuan seluruh variabel $X$ menjelaskan perilaku variabel $Y$ (Adisoewignyho, 2008:277). Hasil perhitungan koefisien determinasi $\left(R^{2}\right)$ variabel diversifikasi produk dan reputasi perusahaan terhadap minat beli ulang konsumen dalam penelitian ini disajikan pada tabel berikut ini 


\section{$J M M$

Tabel 9 Koefisien Determinasi

Model Summary ${ }^{\mathrm{b}}$

\begin{tabular}{lrrrr}
\hline Model & $\mathrm{R}$ & R Square & $\begin{array}{c}\text { Adjusted R } \\
\text { Square }\end{array}$ & $\begin{array}{l}\text { Std. Error of } \\
\text { the Estimate }\end{array}$ \\
\hline 1 & $.697 \mathrm{a}$ & .486 & .475 & .392 \\
\hline
\end{tabular}

a. Predictors: (Constant), X2, X1

b. Dependent Variable: $Y$

Berdasarkan Tabel 9 angka $\mathrm{R}=0.697$, hal ini menunjukan bahwa terjadi korelasi atau hubungan yang sangat kuat antara variabel diversifikasi produk $\left(\mathrm{X}_{1}\right)$, dan reputasi perusahaan $\left(X_{2}\right)$, terhadap minat beli ulang konsumen berkontribusi sebesar $69,7 \%$ yaitu hubungan yang erat, semakin tinggi nilai $\mathrm{R}$ maka, hubungan semakin erat. Semakin mendekati 0 besarnya $R$ suatu persamaan regresi semakin kecil pula pengaruh variabel independen terhadap nilai variabel dependen atau semakin kecil kemampuan model dalam menjelaskan perubahan nilai variabel dependen. Sebaliknya semakin mendekati 1 besarnya $\mathrm{R}$ suatu persamaan regresi, semakin besar pula pengaruh semua variabel independen terhadap nilai variabel dependen, sehingga dapat dikatakan semakin besar kemampuan model yang dihasilkan dalam menjelaskan perubahan nilai variabel dependen.

Nilai $R$ di ketahui sebesar 0.697, maka koefisien determinasi ( $R$ Square) adalah sebesar $0.697 \times 0.697=0,486$ berarti kemampuan variabel bebas yaitu diversifikasi produk $\left(\mathrm{X}_{1}\right)$, dan reputasi perusahaan $\left(\mathrm{X}_{2}\right)$ dalam menjelaskan variansi dari variabel terikat yaitu minat beli ulang adalah sebesar 48,6\%. Berarti terdapat 53,4\% (100\%-46,6\%) varians variabel terikat yang dijelaskan oleh faktor lain yang tidak diteliti.

Angka Adjusted $R$ Square $=0.475$, hasil ini menunjukkan bahwa kemampuan variabel bebas yaitu variabel diversifikasi produk $\left(X_{1}\right)$, dan reputasi perusahaan $\left(X_{2}\right)$ terhadap minat beli ulang berkontribusi sebesar 47,5\%. Sementara 52,5\% (100\%-47,5\%) sisanya dijelaskan oleh variabel lain yang tidak diteliti.

\section{Pembahasan Hasil Penelitian}

\section{Pengaruh Diversifikasi Produk Terhadap Minat Beli ulang}

Berdasarkan hasil pengujian hipotesis pertama yakni diduga terdapat pengaruh variabel diversifikasi produk yang signifikan terhadap minat beli ulang pada UD. Mekar Sari ternyata terbukti. Hasil pengujian hipotesis, menunjukkan bahwa hipotesis ini diterima atau terbukti. Artinya diversifikasi produk berpengaruh positif dan signifikan terhadap minat beli ulang konsumen pada UD. Mekar Sari. Hal ini mengindikasikan bahwa semakin baik diversifikasi produk yang dilakukan perusahaan maka konsumen akan semakin berminat untuk melakukan pembelian ulang.

Berdasarkan hasil pengumpulan data menggunakan kuesioner diperoleh beberapa alasan konsumen ingin melakukan pembelian kembali dan sebagian besar mengemukakan alasannya didasarkan atas beragamnya produk yang ditawarkan (diversifikasi produk yang dilakukan perusahaan). Beberapa dari responden mengungkapkan tentang kepuasannya dalam memilih produk sesuai dengan kebutuhan dan selera masing-masing serta kepuasannya mengenai penyediaan barang yang selalu tersedia pada Toko Mekar Sari. 


\section{$J M M$

Hasil penelitian kali ini sama dengan hasil penelitian sebelumnya yang dilakukan oleh Afifah (2008) dan Oetomo (2009) dimana kembali dibuktikan bahwa ternyata memang benar diversifikasi produk yang dilakukan oleh perusahaan dapat meningkatkan minat beli bahkan minat beli ulang konsumen secara signifikan. Baik dilakukan pada industri jasa seperti kuliner dan properti pada penelitian terdahulu maupun industri produk elektronik sebagaimana yang diteliti pada penelitian kali ini.

\section{Pengaruh Reputasi Perusahaan Terhadap Minat Beli Ulang}

Berdasarkan hasil pengujian hipotesis kedua yakni diduga terdapat pengaruh variabel reputasi perusahaan terhadap minat beli ulang pada UD. Mekar Sari ternyata terbukti. Hasil pengujian hipotesis, menunjukkan bahwa hipotesis ini diterima atau terbukti. Artinya reputasi perusahaan berpengaruh positif dan signifikan terhadap minat beli ulang konsumen pada UD. Mekar Sari. Hal ini mengindikasikan bahwa semakin baik reputasi perusahaan maka konsumen akan semakin berminat untuk melakukan pembelian ulang.

Berdasarkan hasil pengumpulan data menggunakan kuesioner diperoleh beberapa alasan konsumen ingin melakukan pembelian kembali didasarkan atas reputasi perusahaan. Sebagian responden tersebut mengungkapkan tentang kepercayaan mereka terhadap keaslian barang yang dijual dan pelayanan dari pramuniaga Toko Mekar Sari yang dirasakan cukup baik dan memuaskan. Oleh karena itu, dapat dikatakan bahwa pada penelitian kali ini reputasi perusahaan mempengaruhi minat beli ulang secara signifikan pada UD. Mekar Sari. Hasil penelitian kali ini sesuai dengan hasil penelitian sebelumnya yang dilakukan oleh Kuntjara (2007) dimana pada penelitian sebelumnya diperoleh hasil bahwa minat beli ulang konsumen dipengaruhi salah satunya dengan reputasi perusahaan.

\section{KESIMPULAN DAN SARAN}

\section{Kesimpulan}

Berdasarkan hasil pengujian dan analisis yang dilakukan pada Bab sebelumnya, maka hasil penelitian ini dapat disimpulkan sebagai berikut:

1. Diversifikasi produk elektronik yang dilakukan oleh UD. Mekar Sari berpengaruh positif dan signifikan terhadap minat beli ulang konsumennya, yang berarti bahwa jika diversifikasi produk semakin tinggi maka akan semakin tinggi pula keputusan konsumen dalam melakukan pembelian produk elektronik pada UD. Mekar Sari

2. Reputasi perusahaan berpengaruh secara positif dan ssignifikan terhadap minat beli ulang konsumen pada UD. Mekar Sari, yang berarti bahwa jika reputasi perusahaan semakin baik maka minat beli ulang konsumen akan semakin mendukung pada UD. Mekar Sari

\section{Saran}

Berdasarkan kesimpulan tersebut, maka dapat dirumuskan saran sebagai berikut:

1. UD. Mekar Sari sebaiknya untuk terus menerus menambah ragam merek produk yang dijual, karena beberapa responden merasa merek merek yang ada masih kurang terutama untuk merek merek buatan Cina yang relati murah.

2. Reputasi perusahaan dari UD. Mekar Sari memiliki pengaruh terhadap minat beli ulang konsumen secara signifikan, sehingga perusahaan tetap harus menjaga reputasinya tetap baik. Karena Bagaimanapun juga reputasi perusahaan yang diukur dari kompetensi perusahaan, keunggulan perusahaan, kepercayaan pelanggan terhadap perusahaan dan pengalaman perusahaan tetaplah suatu hal yang penting dalam dunia bisnis. 


\section{JMM

\section{Keterbatasan dan Arah Penelitian Selanjutnya}

Pada penellitian ini hanya difokuskan pada variabel diversifikasi produk, repuutasi perusahaan dan minat beli ulang, berkaitan dengan hal tersebut sebaiknya bagi penelitian mendatang diharapkan untuk menambah variabel-variabel lin diluar peelitian ini.

Penelitian ini menggunakan jumlah sampel minimal yaitu hanya 100 orang responden pada UD Mekar Sari, sehingga diharapkan pada penelitian selanjutnya agar dapat menambah jumlah sampel penelitian dan lokasi penelitin sehingga hasi penelitian lebih bervariasi dan dapat dibandingkan.

\section{DAFTAR PUSTAKA}

Achmadi. 2009. Analsis Variabel-Variabel Yang Mempengaruhi Reputasi Perusahaan untuk Membangun Kepercayaan dan Minat Beli Konsumen.

Jurnal pada Universias Muhamadiyah Semarang: tidak diterbitkan

Afifah, Noor. 2008. Pengaruh diversifikasi Produk dan Pemberian Potongan Harga Terhadap Minat Beli Konsumen Di Rumah Makan Cerita Gresik.

Skripsi pada Universitas Muhammadiyah Gresi: tidak diterbitkan

Anderson, E.W.,C Fornell, dan R.R. Lehmann. 1994. " Customer satisfaction, market share and ptofitability: Findings for Sweden". Journall of Marketing, Vol. 58, No.1 :53-56..

Burhaudin. 2006. Analisis Atas Konsekuensi Kepuasan Dan Penyesalan Pada Niat Melakukan Pembelian Ulang dan Niat Melakukan Komplain. Jurnal Ekonomis Bisnis dan Akuntansi. Volume 9 No.1.

Boyd, Walker dan Larreche. 2000. Manajemen Pemasaran : Suatu Pendekatan Strategis dengan Orientasi Global. Edisi Kedua. Jakarta : Erlangga

Carolina, C., \& Rosandy, H. 2013. "Analisa Faktor-faktor yang Mendorong Keputusan Konsumen dalam Memilih Artotel Butik Hotel Surabaya." Jurnal Hospitality dan Manajemen Jasa, 9 (2) : 458-471.

Cronin Jr, J.J.and S. A. Taylor. 1992. Measuring service quality: a reexamination and extenson. The Journal of Marketing: 55-68.

Dharmmesta, B. S. 1999. Loyalitas Pelanggan: Sebuah Kajian Konseptual Sebagai Panduan Bagi Peneliti. Jurnal Ekonomi dan Bisnis Indonesi. Vol. 14 No 3.

Durianto, Darmadi \& Liana, Cecilia. 2004. Analisis efektifitas iklan televise "Softtener Soft \& Fresh" dijakarta dan sekitarnya menggunakan consumer dicision model. Jurnal Ekonomi perusahaan: Vol 11 no 1 ISSN:0854-8153.

Dwisusanti, E. 2006. "Analisis Faktor-faktor yang Berhubungan dengan Keputusan Pelanggan Tetap Menginap di Hotel Garden Palace Surabaya."Jurnal Ilmu-Ilmu Sosial, 6 (2) : 76-81.

Dwityanti, Esthi. 2008. Analisis faktor faktor yang mempengaruhi minat beli ulang konsumen terhadap layanan internet banking mandiri.

Magister Manajemen Universitas Diponegoro: Tidak diterbtkan

Engel,j.f., Blackwell, R.D., Miniard, P.W. 1993. Consumer Behaviour. Edisi 8. Texas: The Dryden Press.

Eszter, Tárkányi, 2008, "The Role of Reference Group Influence in Consumer Behaviour", Theses of Doctoral Dissertation, Széchenyi István University, Multidisciplinary Doctoral School of Social Sciences. 


\section{$J M M$

Evanina, Sianturi., Erida, dan Ade Titi Nifita, 2012. "Pengaruh Kelompok Referensi Dan Gaya Hidup Terhadap Keputusan Menggunakan Blackberry". Jurnal Manajemen Fakultas Ekonomi Universitas Jambi, Vol1No.2April-Juni 2012, ISSN:2302-4682.

Ferdinand, Augusty. 2002. Pengembangan Minat Beli Merek Ekstensi. Semarang: Badan Penerbit Universitas Diponegoro.

Ferdinand, A.T.2006. Metode Penelitian Manajemen. BP Undip. Semarang.

Fornell, Clase.1992. A National Customer Satisfiaction Barometer: The Swedish Experience. Jural of Marketing. Vol 56

Fure. 2013. Keberagaman Produk, Harga, dan kualitas pelayanan pengaruhnya terhadap minat beli pada pasar tradisional Bersehati. Semarang: Badan Penerbit Universitas Diponegoro.

Harikusmawan, G.B.D., \& Mandala, K. 2014. "Faktor-faktor yang Mempengaruhi Keputusan Wisatawan Menginap di Villa Akasha Beach Estate Kerobokan Badung". Jurnal Online FEB Universitas Udayana : 1182-1196.

Guiltinan, Joseph P. \& Gordon W. Paul. 1992. Manajemen Pemasaran. Jakarta: Erlangga.

Herbig, Paul, John Milewichz \& Jim Golden, 1994, A Model of Reputation Building \& Destruction, Journal of Business Research, Vol. 31

James F. Engel, dll. 1995. Perilaku Konsumen, cetakan 1. Penerbit: Binarupa Aksara: Jakarta

Kotler. Philip. 2001. Manajemen Pemasaran : Analisis, Perencanaan, Implementasi dan Kontrol. Jakarta : PT. Prehallindo

Kuntjara.2007. Analisis Faktor-faktor yang mempengaruhi Minat Beli Ulang Konsumen. Tesis Magister Manajemen Universitas Diponegoro: Tidak diterbtkan.

Kurniawati, Dyah. 2010. Sikap Terhadap Merek dan Implikasinya Terhadap Minat Beli Ulang dengan studi kasus produk mi instan Indomie.

Magister Manajemen Universitas Diponegoro: Tidak diterbtkan.

Lattan, Hengky. 2012. Structural Equation Modelling Konsep dan Aplikasi Mengunakan Program Lisrel 8.80. Bandung: Alfa Beta.

Lauren. Adrian.2012. Melaksanakan strategi pemasaran melalui strategi diversifikasi produk dalam menghadapi era globalisasi.

Laiunita, Mina, Novianty Eka, 2013. Diversifikasi Produk Elektronik Terhadap Minat Beli Ulang Dengan Reputasi Perusahaan Sebagai Variabel Moderator Pada UD.Sabar Mrnaanti

Magister Manajemen Universitas Mataram: Tidak diterbtkan.

Nazir, Moh. 2005. Metodologi Penelitian. Jakarta: Ghalia Indonesia.

Oetomo, Ali.2009. Analsis Pengaruh Keragaman Menu, Persepsi Harga dan Lokasi terhadap Minat Beli Ulang Konsumen. Jurnal Ekonomi: tidak diterbitkan.

Oliver, Richard. 1993. A Conceptual Model of Service Quality and Service Sattisfaction: Compatible Goal, Different Concept, in Advance in Service Marketing and Management. Vol 2: p.65 -85.

Purba, Jan Horas V. 2005. Strategi diversifikasi Produk Terhadap Tingkat Omzet Penjualan (Studi Kasus Pada PT Surya Pelita Pratama). Jurnal Ilmiah Ranggagading: Volume 5. No.1.

Ramli, Moh.2008. Analisis Pengaruh Sikap Konsumen dan Diversifiksi Produk Terhadap Keputusan Pembelian Produk. Skripsi pada Universitas Mataram: tidak diterbitkan.

Sari, Darlina Yunia (2013), Pengaruh Kualitas Pelayanan, Reputasi Perusahaan, Atribut Produk, Dan Cita Rasa Terhadap Minat Beli Ulang Konsumen Teh Botol Sosro

Tesis Program Study Jurusan Ilmu Administrasi, Fakultas Ilmu Sosial dan Ilmu Politik, Universitas Jember (UNEJ): tidak diterbitkan 


\section{JMM JURNAL MAGISTER MANAJEMEN

Subhan, Muh. 2006. Analsis faktor-faktor yang berpengaruh terhadap reputasi suatu perusahan. Tesis Program Study Magister Management. Universitas Diponegoro: tidak diterbitkan

Sugiyono.2012. Statistik Untuk Penelitian. Bandung: CV Afabeta

Tjiptono, Fandy. 2008. Strategi Pemasaran. Edisi ketiga. Penerbit Andi: Yogyakarta 